Syntax Literate: Jurnal Ilmiah Indonesia p-ISSN: 2541-0849 e-ISSN: 2548-1398

Vol. 6, Spesial Issue No. 1, November 2021

\title{
EVALUASI USABILITY PADA WEBSITE PUSTAKAWAN GANECA DIGITAL MENGGUNAKAN USER EXPERIENCE QUESTIONNAIRE DAN THINK ALOUD
}

\section{Made Agus Oka Gunawan, I Made Agus Widiana Putra, Kadek Laksmi Damayanthi}

Program Studi Sistem Informasi, Universitas Tabanan, Bali, Indonesia

Email: agusokagunawan@gmail.com,imadeagusclass@gmail.com,

deklaksmi2016@gmail.com

\begin{abstract}
Abstrak
Ganeca Digital merupakan aplikasi perpustakaan digital yang dikembangkan berbasis website dan aplikasi mobile. Pada 2 tahun berjalannya layanan aplikasi Ganeca Digital ini, masih terdapat pengguna yang mengeluhkan penggunaan Ganeca Digital, salah satunya adalah dari halaman pustakawan. Sehingga perlu dilakukan evaluasi lanjutan untuk mendapatkan rekomendasi pengembangan Ganeca Digital. Salah satu metode evaluasi berbasis pengguna yang dapat digunakan adalah evaluasi usability. Berdasarkan kajian yang dilakukan, akan dikombinasikan teknik User Experience Questionnaire dan Think Aloud dalam melakukan evaluasi berbasis pengguna. User Experience Questionnaire (UEQ) mencakup enam aspek dengan 26 butir pernyataan. Analisis data UEQ dilakukan dengan menggunakan UEQ Data Analysis Tool dengan membandingkan nilai setiap aspek dengan kumpulan data produk yang tersedia. Pada UEQ akan dilibatkan 20 responden untuk mendapatkan nilai kepuasan pengguna. Evaluasi Think Aloud melibatkan 10 responden berdasarkan hasil UEQ. Pada penelitian ini digunakan 25 skenario tugas yang disesuaikan dengan fungsional yang ada. Hasil analisis menunjukkan bahwa aspek daya tarik, ketepatan, stimulasi dan kebaruan termasuk kategori sangat baik. Hasil analisis menunjukkan prioritas perbaikan dapat difokuskan pada aspek kejelasan yang termasuk kategori diatas rata-rata dan aspek efisiensi yang termasuk kategori baik. Adapun nilai rata-rata setiap aspek adalah sebagai berikut: aspek daya tarik sebesar 1,77; aspek kejelasan sebesar 1,39; aspek efisiensi sebesar 1,65; aspek ketepatan sebesar 1,84; aspek stimulasi sebesar 1,86 dan aspek kebaruan sebesar 1,54. Hasil evaluasi Think Aloud berhasil memperoleh 10 permasalahan yang dikemukakan responden. Pengembangan untuk penelitian selanjutnya, dapat digunakan teknik Performance Measurement untuk membandingkan hasil evaluasi antara pakar dan pengguna aplikasi.
\end{abstract}

Kata Kunci: evaluasi; usability; user experience; kuesioner; think aloud.

\section{Abstract}

Ganeca Digital is a digital library application developed based on websites and mobile applications. In the 2 years since the Ganeca Digital application service has been running, there are still users who complain about using Ganeca Digital, one

$\begin{array}{ll}\text { How to cite: } & \text { Gunawan. I. M. A. O., I Made Agus Widiana Putra \& Kadek Laksmi Damayanthi (2021). Evaluasi } \\ & \text { Usability pada Website Pustakawan Ganeca Digital Menggunakan User Experience Questionnaire dan } \\ & \text { Think Aloud. Syntax Literate: Jurnal Ilmiah Indonesia, 6(1). } \\ \text { E-ISSN: } & \text { 2548-1398 } \\ \text { Published by: } & \text { Ridwan Institute }\end{array}$


of which is from the librarian's page. So it is necessary to carry out a further evaluation to obtain recommendations for the development of Ganeca Digital. One of the user-based evaluation methods that can be used in usability evaluation. Based on the study conducted, the User Experience Questionnaire and Think Aloud techniques will be combined in conducting user-based evaluations. The User Experience Questionnaire (UEQ) covers six aspects with 26 statements. UEQ data analysis was carried out using the UEQ Data Analysis Tool by comparing the value of each aspect with the available product data set. In UEQ, 20 respondents will be involved to get user satisfaction scores. The Think Aloud evaluation involved 10 respondents based on the UEQ results. In this study, 25 task scenarios were used that were adapted to existing functionalities. The results of the analysis show that the aspects of attractiveness, accuracy, stimulation, and novelty are in the excellent category. The results show that improvement priorities can be focused on aspects of perspicuity which are included in the above-average category and aspects of efficiency which are included in the good category. The average value of each aspect is as follows: attractiveness 1.77; perspicuity 1.39; efficiency 1.65; accuracy 1.84; stimulation 1.86 and novelty 1.54. The results of the Think Aloud evaluation succeeded in obtaining 10 problems raised by the respondents. For further research, Performance Measurement can be used to compare the evaluation between experts and end-users.

Keywords: evaluation; usability; user experience; questionnaire; think aloud.

\section{Pendahuluan}

Seiring dengan pesatnya perkembangan teknologi informasi, banyak layanan dan produk dihasilkan untuk mendukung tercapainya tujuan seorang individu. Layanan dan produk ini dapat berupa aplikasi berbasis website, desktop atau mobile. Salah satu bentuk pemanfaatan teknologi informasi adalah dengan dikembangkannya aplikasi Ganeca Digital. Ganeca Digital merupakan aplikasi perpustakaan digital yang dikembangkan berbasis website dan aplikasi mobile. Pada Ganeca Digital, terdapat beberapa level akses pengguna, yaitu halaman pustakawan dan pengguna. Pengguna dapat melakukan proses peminjaman buku pada suatu perpustakaan secara digital, dimana pengelolaan perpustakaan dilakukan oleh pustakawan. Saat ini terdapat 100 ribu pengguna aplikasi dengan 700 perpustakaan yang dikelola oleh pustakawan.

Pada 2 tahun berjalannya layanan aplikasi Ganeca Digital ini, masih terdapat pengguna yang mengeluhkan penggunaan aplikasi mobile berdasarkan review yang diberikan di Google Playstore. Masukan yang diberikan oleh pengguna aplikasi mobile dianalisis untuk melakukan perbaikan aplikasi mobile. Permasalahan yang perlu dilakukan perbaikan tidak hanya dari aplikasi mobile, namun juga dari halaman website pustakawan. Selama berjalan, para pustakawan melakukan komunikasi menggunakan whatsapp sehingga data-data perbaikan yang dilakukan kadang terlewati atau tertumpuk dengan chat lain. Oleh sebab itu, untuk mendapatkan feedback yang lebih baik dari pustakawan, perlu dilakukan evaluasi pada halaman website pustakawan yang melibatkan pustakawan langsung. 
Evaluasi usability merupakan salah satu metode evaluasi yang dapat digunakan dalam melakukan menilai kebermanfaatan (usability) sebuah produk (Paramitha, 2018). Pada evaluasi ini, dilakukan penilaian terkait seberapa baik dan puas pengguna dalam menggunakan sebuah produk atau layanan. Evaluasi ini dapat dikategorikan menjadi 3 kategori, yaitu inspection, testing dan inquiry (Gupta, 2015). Setiap kategori memiliki teknik-teknik tersendiri dalam melakukan evaluasi. Berdasarkan permasalahan yang telah dijabarkan sebelumnya, evaluasi dilakukan berbasis pengguna yaitu pustakawan Ganeca Digital. Sehingga pada penelitian ini digunakan teknik evaluasi dari kategori testing dan inquiry.

Usability testing digunakan untuk mengobservasi pengguna saat berinteraksi dengan sistem, sedangkan inquiry digunakan untuk memperoleh data dalam mengetahui kepuasan pengguna (Tantri Fajarini, 2020). Evaluasi inquiry memiliki beberapa teknik evaluasi, salah satunya adalah Questionnaire (Putri Ambarwati, 2021). User Experience Questionnaire merupakan salah satu jenis kuesioner yang mampu memberikan gambaran aspek kebermanfaatan hingga pengalaman pengguna (Dewi, 2020). User Experience Questionnaire (UEQ) terdiri dari 26 butir pernyataan berdasarkan 6 aspek pengalaman pengguna (Wijaya, 2021). Adapun 6 aspek tersebut, diantaranya daya tarik, kejelasan, efisiensi, ketepatan, stimulasi dan kebaruan (Schrepp, 2019). Penerapan UEQ biasanya dibutuhkan waktu selama 3 - 5 menit untuk membaca dan menyelesaikan kuesioner (Santoso, 2016). Keunggulan lainnya dari UEQ adalah dapat diakses secara gratis dan tersedia dalam versi Bahasa Indonesia (Mochammad Aldi Kushendriawan, 2021). Analisis data UEQ dilakukan dengan menggunakan UEQ Data Analysis Tool dengan membandingkan nilai setiap aspek dengan kumpulan data produk yang tersedia (Schrepp, 2017).

Evaluasi testing memiliki beberapa teknik evaluasi, salah satunya adalah Think Aloud (Astuti, 2017). Teknik ini memungkinkan responden yang merupakan pengguna dari suatu produk untuk menceritakan hal-hal yang dipikirkan saat menggunakan produk tersebut (Roni, 2018). Teknik ini memerlukan beberapa skenario yang harus dikerjakan oleh setiap responden (Hendradewa, 2017). Pada penelitian sebelumnya, 2 teknik ini dapat dikombinasikan untuk memaksimalkan hasil evaluasi yang dilakukan (Indrawan, 2020). Penelitian sebelumnya, menunjukkan bahwa tahapan testing dilakukan terlebih dahulu, untuk selanjutnya dilakukan tahapan inquiry. Pada penelitian ini, tahapan penelitian akan dilakukan dengan diawali tahapan inquiry kemudian dilanjutkan tahapan testing.

Berdasarkan pemaparan di atas, salah satu cara yang dapat dilakukan untuk mendapatkan masukan terkait perbaikan website pustakawan adalah dengan melakukan evaluasi usability. Oleh karena itu, peneliti ingin melakukan penelitian mengenai "Evaluasi Usability Pada Website Pustakawan Ganeca Digital Menggunakan User Experience Questionnaire Dan Think Aloud". Penelitian ini diharapkan menghasilkan tingkat kepuasan pengguna berdasarkan hasil UEQ disertai masukan-masukan perbaikan berdasarkan hasil teknik Think Aloud. 
I Made Agus Oka Gunawan, I Made Agus Widiana Putra, Kadek Laksmi Damayanthi

\section{Metode Penelitian}

Penelitian Evaluasi Usability Pada Website Pustakawan Ganeca Digital ini adalah penelitian berbasis pengguna dengan menggunakan metode deskriptif analitis. Metode berupaya menjelaskan atau mencatat kondisi atau sikap untuk menjelaskan apa yang ada saat ini (Indriyani, 2017). Penelitian ini menganalisis secara deskriptif mengenai penggunaan Website Pustakawan Ganeca Digital berdasarkan aspek usability-nya. Tahapan penelitian yang dilakukan digambarkan dengan diagram alir penelitian, seperti ditunjukkan pada pada Gambar 1.

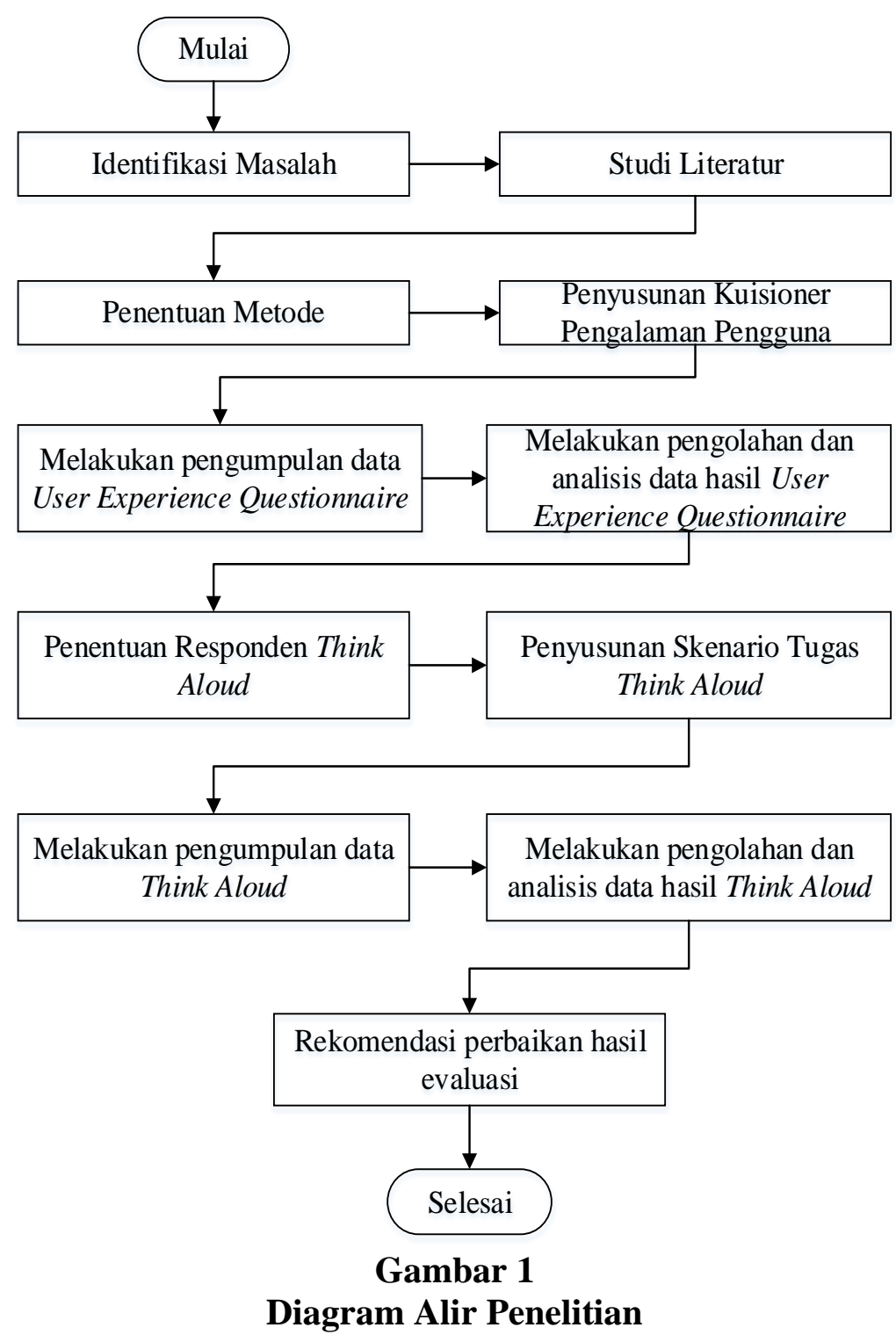

Analisis awal dilakukan terkait identifikasi masalah dengan studi literatur. Berdasarkan studi literatur, didapatkan bahwa evaluasi dilakukan dengan menggunakan User Experience Questionnaire dan Think Aloud. Pada tahap awal, akan dilakukan pengumpulan data kepuasan pengguna dalam penggunaan halaman Pustakawan. Kuesioner yang digunakan merupakan kuesioner pengalaman pengguna berbasis Bahasa 
Indonesia dengan disertai pernyataan tambahan untuk memperjelas (Hinderks, 2019), salah butirnya seperti ditunjukkan Gambar 2.

\begin{tabular}{|c|c|c|c|c|c|c|c|c|c|}
\hline & & 1 & 2 & 3 & 4 & 5 & 6 & 7 & \\
\hline $\begin{array}{l}\text { Produk ini dapat } \\
\text { dipahami }\end{array}$ & tak dapat dipahami & o & 0 & 0 & 0 & 0 & $\sqrt{ }$ & 0 & dapat dipahami \\
\hline
\end{tabular}

\section{Gambar 2}

\section{Butir Kuesioner}

Penggunaan 20-30 responden pada evaluasi kepuasan pengguna sudah dapat memberikan hasil yang baik dan stabil (Schrepp, 2017). Sehingga pada penelitian ini, tahap awal akan memilih 20 responden dari 700 pustakawan yang ada di Ganeca Digital. Hasil kuesioner yang telah diisi oleh pengguna, selanjutnya dianalisis menggunakan UEQ Data Analysis Tool. Analisis UEQ dilakukan dengan menghitung rata-rata nilai setiap aspek yang diberikan oleh setiap responden pada 26 butir pernyataan. Hasil UEQ dilakukan uji benchmark dan akan diinterpretasikan sesuai dengan

Tabel 1 berikut (Schrepp, 2017).

Tabel 1

Rentang Benchmark

\begin{tabular}{cllllll}
\hline \multirow{2}{*}{ Aspek } & \multicolumn{5}{c}{ Kategori } \\
\cline { 2 - 6 } & Sangat Baik & Baik & Diatas Rata-Rata & Dibawah Rata-Rata & Buruk \\
\hline Daya Tarik & $\geq 1.75$ & $\geq 1.52$ & $\geq 1.17$ & $\geq 0.7$ & $<0.7$ \\
& & $<1.75$ & $<1.52$ & $<1.17$ & \\
\hline \multirow{2}{*}{ Kejelasan } & $\geq 1.9$ & $\geq 1.56$ & $\geq 1.08$ & $\geq 0.64$ & $<0.64$ \\
& & $<1.9$ & $<1.56$ & $<1.08$ & $<0.54$ \\
\hline Efisiensi & $\geq 1.78$ & $\geq 1.47$ & $\geq 0.98$ & $\geq 0.54$ & $<0.78$ \\
& & $<1.78$ & $<1.47$ & $<0.98$ & $<0.5$ \\
\hline \multirow{2}{*}{ Ketepatan } & $\geq 1.65$ & $\geq 1.48$ & $\geq 1.14$ & $\geq 0.78$ & \\
& & $<1.65$ & $<1.48$ & $<1.14$ & $<0.3$ \\
\hline \multirow{2}{*}{ Stimulasi } & $\geq 1.55$ & $\geq 1.31$ & $\geq 0.99$ & $\geq 0.5$ & \\
& & $<1.55$ & $<1.31$ & $<0.99$ & \\
\hline Kebaruan & $\geq 1.4$ & $\geq 1.05$ & $\geq 0.71$ & $\geq 0.3$ & \\
& & $<1.4$ & $<1.05$ & & $<0.71$ & \\
\hline
\end{tabular}

Interpretasi dari masing-masing rentang benchmark adalah sebagai berikut (Nurdin, 2020).

a. Sangat Baik: termasuk dalam kisaran $10 \%$ produk yang memiliki skor tertinggi.

b. Baik: $10 \%$ produk pada dataset memiliki skor yang lebih tinggi, sedangkan $75 \%$ lainnya lebih rendah.

c. Diatas Rata-Rata: $25 \%$ produk pada dataset memiliki skor yang lebih tinggi, sedangkan 50\% lainnya lebih rendah.

d. Dibawah Rata-Rata: $50 \%$ produk pada dataset memiliki skor yang lebih tinggi, sedangkan $25 \%$ lainnya lebih rendah.

e. Buruk: termasuk dalam kisaran $25 \%$ produk yang memiliki skor terendah. 
I Made Agus Oka Gunawan, I Made Agus Widiana Putra, Kadek Laksmi Damayanthi

Contoh hasil pengolahan data menggunakan UEQ Data Analysis Tool ditunjukkan pada Gambar 3.

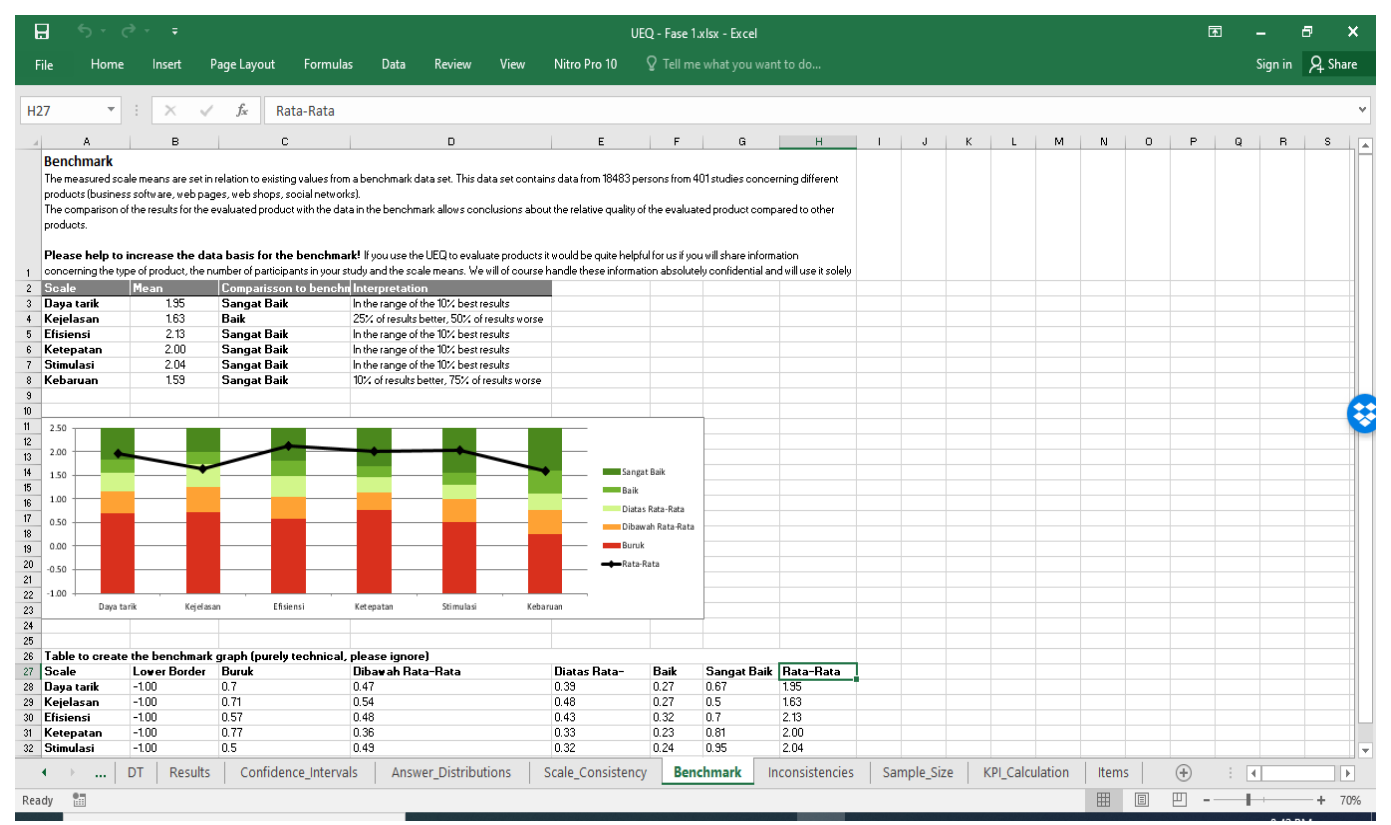

Gambar 3

Contoh Hasil Pengolahan Data

Berdasarkan hasil kepuasan pengguna, selanjutnya akan dipilih responden untuk evaluasi Think Aloud. Penggunaan Think Aloud memerlukan 8 sampai 10 orang responden yang merupakan pengguna sistem, dimana jumlah tersebut sudah cukup untuk memahami perilaku pengguna dalam melakukan sejumlah skenario tugas yang diberikan (Pratama, 2019). Penyusunan skenario tugas disesuaikan dengan fungsional yang ada pada halaman website pustakawan. Pada penelitian ini, ada 25 skenario tugas yang disesuaikan dengan fungsionalnya.

Tabel 2 menunjukkan beberapa skenario tugas yang akan dilakukan oleh tiap responden.

Tabel 2

Contoh Skenario Tugas

\begin{tabular}{llllll}
\hline No & Fungsional & \multicolumn{4}{c}{ Tugas } \\
\hline 1 & Hak Akses & $\begin{array}{l}\text { 1. Silahkan login ke dalam halaman pustakawan dengan menginputkan } \\
\text { email dan password Anda }\end{array}$ \\
\hline 2 & Profil & $\begin{array}{l}\text { 1. Silahkan akses halaman profil, lalu lakukan perubahan logo } \\
\text { perpustakaan Anda. }\end{array}$ & & & \\
& & $\begin{array}{l}\text { 2. Anda ingin merubah password Anda, silahkan ubah password Anda saat } \\
\text { ini. }\end{array}$ & & \\
& & 3. Ubah status perpustakaan Anda menjadi private. & \\
\hline 3 & Buku & $\begin{array}{l}\text { 1. Tambahkan kategori baru dengan nama Teknologi. } \\
\text { 2. Cari data penerbit Ganeca Digital. }\end{array}$ \\
& 3. Tambahkan 1 file buku baru pada menu Media & \\
\end{tabular}


Pada Think Aloud, responden akan diberikan kesempatan untuk menceritakan apa yang dipikirkan pada saat mengerjakan setiap tugas, seperti permasalahan atau masukan dalam memperbaiki website. Setiap permasalahan atau masukan tersebut akan dicatat untuk selanjutnya dirangkum untuk mendapatkan kesimpulan akhir dari permasalahan dan masukan dari semua responden. Rekomendasi akhir dalam penelitian ini adalah daftar rekomendasi perbaikan dari Website Pustakawan Ganeca Digital. Rekomendasi perbaikan yang didapatkan berdasarkan evaluasi yang dilakukan akan divalidasi dengan tim dari Ganeca Digital.

\section{Hasil dan Pembahasan}

Hasil evaluasi UEQ dilakukan oleh 20 responden. Hasil rekapitulasi nilai setiap butir pernyataan dalam kuesioner dapat dilihat pada pada

Tabel 3. Hasil rekapitulasi tersebut selanjutnya diolah menggunakan UEQ Data Analysis Tool. Tahap awal pengolahan data dilakukan dari transformasi data awal. Tahap selanjutnya, data diolah untuk mencari nilai rata-rata masing-masing aspek pengalaman pengguna.

Tabel 3

Rekapitulasi Nilai Setiap Butir Pernyataan Dalam Kuesioner

\begin{tabular}{|c|c|c|c|c|c|c|c|c|c|c|c|c|c|}
\hline \multirow{2}{*}{ Responden } & \multicolumn{13}{|c|}{ Butir Pernyataan } \\
\hline & 1 & 2 & 3 & 4 & 5 & 6 & 7 & 8 & 9 & 10 & 11 & 12 & 13 \\
\hline R01 & 3 & 5 & 1 & 2 & 1 & 6 & 6 & 7 & 1 & 1 & 7 & 1 & 5 \\
\hline R02 & 5 & 6 & 3 & 3 & 2 & 5 & 5 & 5 & 1 & 2 & 5 & 2 & 5 \\
\hline R03 & 6 & 5 & 1 & 0 & 2 & 6 & 6 & 7 & 2 & 2 & 6 & 1 & 6 \\
\hline R04 & 4 & 4 & 5 & 2 & 1 & 3 & 7 & 6 & 1 & 2 & 6 & 3 & 4 \\
\hline R05 & 4 & 3 & 2 & 2 & 1 & 7 & 7 & 3 & 1 & 1 & 7 & 1 & 6 \\
\hline R06 & 5 & 6 & -1 & 2 & 1 & 4 & 5 & 4 & 6 & 4 & 4 & 2 & 3 \\
\hline R07 & 4 & 5 & 5 & 5 & 6 & 5 & 5 & 5 & 4 & 5 & 5 & 5 & 4 \\
\hline R08 & 4 & 6 & 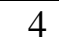 & & 6 & 5 & 6 & 5 & 2 & 5 & 5 & 2 & 5 \\
\hline R09 & 7 & 7 & 1 & 1 & 1 & 7 & 4 & 6 & 1 & 1 & -1 & 1 & 5 \\
\hline R10 & 7 & 7 & 1 & 2 & 3 & 5 & 7 & 3 & 2 & 2 & 7 & 1 & 6 \\
\hline R11 & 5 & 5 & 4 & 1 & 1 & 6 & 5 & 6 & 1 & 2 & 7 & 1 & 3 \\
\hline R12 & 7 & 6 & 2 & 2 & 1 & 6 & 6 & 6 & 2 & 2 & 6 & 2 & 3 \\
\hline R13 & 7 & 7 & 2 & 2 & 2 & 7 & 7 & 6 & 1 & 1 & 5 & 2 & 5 \\
\hline R14 & 6 & 7 & 6 & 1 & 1 & 6 & 7 & 7 & 2 & 2 & 4 & 1 & 5 \\
\hline R15 & 5 & 5 & 6 & 4 & 1 & 3 & 5 & 5 & 2 & 2 & 7 & 3 & 2 \\
\hline R16 & 7 & 7 & 2 & 2 & 2 & 6 & 6 & 6 & 1 & 2 & 7 & 1 & 6 \\
\hline R17 & 6 & 7 & 2 & 2 & 1 & 7 & 3 & 6 & 2 & 1 & 3 & 1 & 3 \\
\hline R18 & 5 & 6 & 6 & 2 & 1 & 5 & 6 & 5 & 1 & 3 & 7 & 2 & 6 \\
\hline R19 & 5 & 5 & 3 & 3 & 3 & 5 & 5 & 5 & 3 & 3 & 5 & 3 & 5 \\
\hline R20 & 6 & 6 & 2 & 2 & 1 & 6 & 5 & 5 & 2 & 3 & 6 & 1 & 4 \\
\hline \multirow{2}{*}{ Responden } & \multicolumn{13}{|c|}{ Butir Pernyataan } \\
\hline & 14 & 15 & 16 & 17 & 18 & 19 & 20 & 21 & 22 & 23 & 24 & 25 & 26 \\
\hline R01 & 6 & 6 & 7 & 1 & 1 & 1 & 6 & 1 & 3 & 1 & 2 & 2 & 6 \\
\hline R02 & 5 & 6 & 6 & - & 2 & 2 & 6 & 3 & 5 & 1 & 1 & 2 & 5 \\
\hline R03 & 6 & 6 & 6 & 1 & 1 & 1 & 6 & 2 & 5 & 1 & 1 & 1 & 7 \\
\hline
\end{tabular}


I Made Agus Oka Gunawan, I Made Agus Widiana Putra, Kadek Laksmi Damayanthi

\begin{tabular}{llllllllllllll}
\hline R04 & 5 & 6 & 7 & 2 & 3 & 2 & 7 & 5 & 6 & 2 & 3 & 1 & 7 \\
\hline $\mathbf{R 0 5}$ & 7 & 7 & 7 & 1 & 1 & 1 & 7 & 1 & 7 & 1 & 1 & 1 & 7 \\
\hline $\mathbf{R 0 6}$ & 4 & 6 & 4 & 2 & 4 & 3 & 4 & 5 & 5 & 3 & 2 & 3 & 2 \\
\hline $\mathbf{R 0 7}$ & 5 & 5 & 5 & 2 & 2 & 3 & 5 & 4 & 3 & 6 & 6 & 6 & 6 \\
\hline $\mathbf{R 0 8}$ & 5 & 2 & 6 & 4 & 2 & 3 & 6 & 3 & 3 & 3 & 3 & 2 & 3 \\
\hline $\mathbf{R 0 9}$ & 7 & 7 & 6 & 2 & 1 & 1 & 5 & 1 & 5 & 1 & 1 & 1 & 7 \\
\hline $\mathbf{R 1 0}$ & 6 & 7 & 7 & 1 & 1 & 1 & 7 & 3 & 4 & 1 & 1 & 2 & 7 \\
\hline $\mathbf{R 1 1}$ & 6 & 6 & 5 & 1 & 1 & 1 & 5 & 2 & 6 & 2 & 2 & 2 & 7 \\
\hline $\mathbf{R 1 2}$ & 5 & 6 & 7 & 2 & 2 & 2 & 3 & 2 & 7 & 2 & 2 & 1 & 7 \\
\hline $\mathbf{R 1 3}$ & 7 & 4 & 4 & 1 & 2 & 2 & 6 & 2 & 6 & 2 & 2 & 1 & 7 \\
\hline $\mathbf{R 1 4}$ & 6 & 7 & 6 & 2 & 1 & 1 & 7 & 2 & 6 & 1 & 2 & 2 & 7 \\
\hline $\mathbf{R 1 5}$ & 5 & 6 & 5 & 1 & 3 & 3 & 5 & 5 & 4 & 1 & 3 & 3 & 4 \\
\hline $\mathbf{R 1 6}$ & 6 & 7 & 7 & 1 & 1 & 1 & 4 & 1 & 7 & 1 & 2 & 1 & 7 \\
\hline $\mathbf{R 1 7}$ & 7 & 7 & 4 & 1 & 2 & 2 & 6 & 1 & 5 & 1 & 2 & 2 & 7 \\
\hline $\mathbf{R 1 8}$ & 3 & 5 & 5 & 2 & 1 & 2 & 3 & 2 & 6 & 7 & 2 & 2 & 1 \\
\hline $\mathbf{R 1 9}$ & 5 & 3 & 5 & 3 & 3 & 3 & 5 & 3 & 5 & 3 & 3 & 3 & 5 \\
\hline R20 & 4 & 5 & 6 & 2 & 2 & 2 & 6 & 3 & 5 & 2 & 4 & 2 & 7 \\
\hline
\end{tabular}

Hasil dari UEQ juga dibandingkan pada benchmark seperti ditunjukkan Gambar 4. Pada UEQ Data Analysis Tool rata - rata nilai dari masing - masing aspek sudah dihubungkan dengan kumpulan data yang ada pada benchmark.

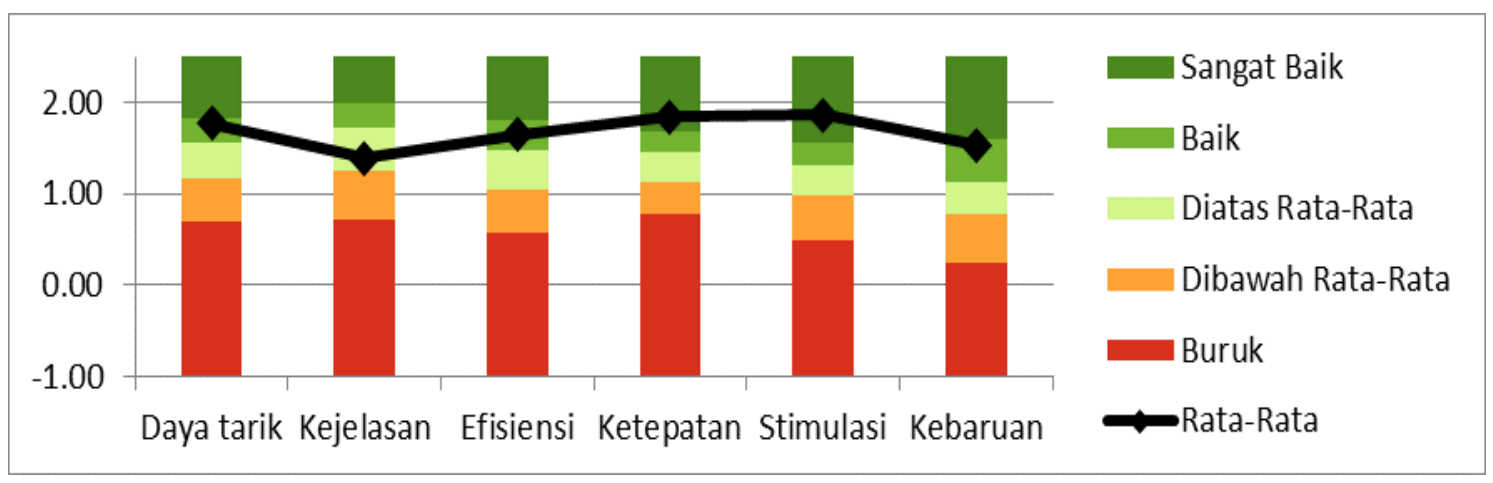

\section{Grafik Perbandingan Benchmark}

Hasil perbandingan rata-rata aspek pengalaman pengguna pada benchmark ditunjukkan pada

Tabel 4.

Tabel 4

Hasil Benchmark SIsKA

\begin{tabular}{lcc}
\multicolumn{1}{c}{ Aspek } & Rata-Rata & Perbandingan Pada Benchmark \\
\hline Daya tarik & 1.77 & Sangat Baik \\
\hline Kejelasan & 1.39 & Diatas Rata-Rata \\
\hline Efisiensi & 1.65 & Baik \\
\hline Ketepatan & 1.84 & Sangat Baik \\
\hline Stimulasi & 1.86 & Sangat Baik \\
\hline Kebaruan & 1.54 & Sangat Baik \\
\hline
\end{tabular}


Berdasarkan data pada tabel 4, didapatkan bahwa aspek kejelasan dan efiensi menjadi 2 aspek yang perlu diperbaiki. Untuk mendapatkan rekomendasi perbaikan, maka langkah selanjutnya adalah dengan melakukan evaluasi Think Aloud terhadap 10 responden yang memberikan nilai yang kecil terhadap kedua aspek tersebut. Berdasarkan proses Think Aloud yang dilakukan tiap responden, maka dihasilkan daftar permasalahan dan masukan dari aplikasi Smart BTW, yang dapat dilihat pada

Tabel 5 berikut.

\section{Tabel 5}

Kesimpulan Data Think Aloud

\begin{tabular}{|c|c|c|}
\hline No & & \\
\hline 1. & $\begin{array}{l}\text { nber tidak } \\
\text { ida bug }\end{array}$ & $\begin{array}{l}\text { Fitur ini bisa disesuaikan, de } \\
\text { member, sehingga penambahan } \\
\text { dapat dilakukan dalam } 1 \text { kali peny }\end{array}$ \\
\hline 2. & $\begin{array}{l}\text { Kesalahan } \\
\text { menu mem }\end{array}$ & pengembang Ganeca \\
\hline 3. & $\begin{array}{l}\text { nya bisa } \\
\text { an saja }\end{array}$ & $\begin{array}{l}\text { an filter sehingga bisa melihat statistik di } \\
\text { a }\end{array}$ \\
\hline & $\begin{array}{lrr}\text { Informasi } & \text { statistik } & \text { dan } \\
\text { informasi halaman } & \text { menu } \\
\text { Borrow tidak sama } & \end{array}$ & $\begin{array}{l}\text { ki karena akan membantu pustakawan } \\
\text { n data }\end{array}$ \\
\hline & $\begin{array}{l}\text { lar buku } \\
\text { hui }\end{array}$ & $\begin{array}{l}\text { Perlu ditambahkan kolom informasi jumlah buku di } \\
\text { Menu Book }\end{array}$ \\
\hline & $\begin{array}{r}\text { getahui } \\
\text { sering }\end{array}$ & $\begin{array}{l}\text { Perlu penambahan informasi kategori buku di menu } \\
\text { Borrow }\end{array}$ \\
\hline 7. & $\mathrm{nu}$ & $\begin{array}{l}\text { Menu-menu perlu dinamakan sesuai fungsionalnya, } \\
\text { seperti menu Setting, perlu disesuaikan menjadi Setting } \\
\text { Duration karena hanya mengatur waktu durasi } \\
\text { peminjaman sajan. }\end{array}$ \\
\hline & $\begin{array}{c}\text { tidak bisa } \\
\text { masi yang ada }\end{array}$ & $\begin{array}{l}\text { ort excel beberapa menu, seperti Book, } \\
\text { y dan Borrow }\end{array}$ \\
\hline & $\begin{array}{l}\text { Menambahkan buku } \\
\text { langkahnya sangat panjang }\end{array}$ & $\begin{array}{l}\text { ambahkan, sehingga } \\
\text { ku. }\end{array}$ \\
\hline & uan di & $\begin{array}{r}\text { membantu } \\
\text { panduannya } \\
\text { a Digital }\end{array}$ \\
\hline
\end{tabular}

Rekomendasi perbaikan ini diperoleh berdasarkan analisis yang dilakukan dari evaluasi yang telah dilakukan. 
I Made Agus Oka Gunawan, I Made Agus Widiana Putra, Kadek Laksmi Damayanthi

Tabel 6 menunjukkan beberapa wireframe rekomendasi perbaikan halaman website pustakawan Ganeca Digital berdasarkan rekomendasi perbaikan yang dihasilkan dari evaluasi Think Aloud.

Tabel 6

Wireframe Perbaikan

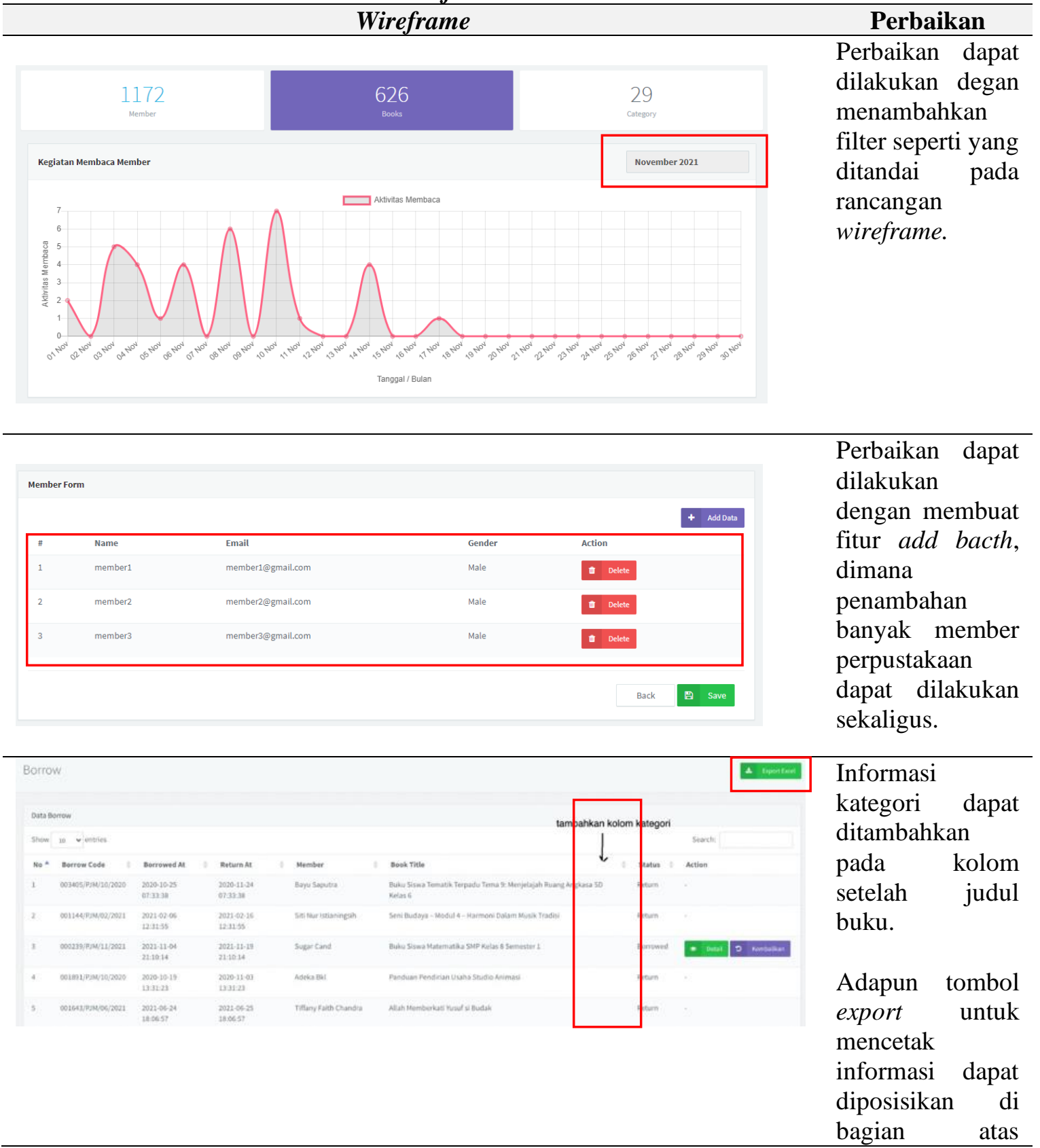




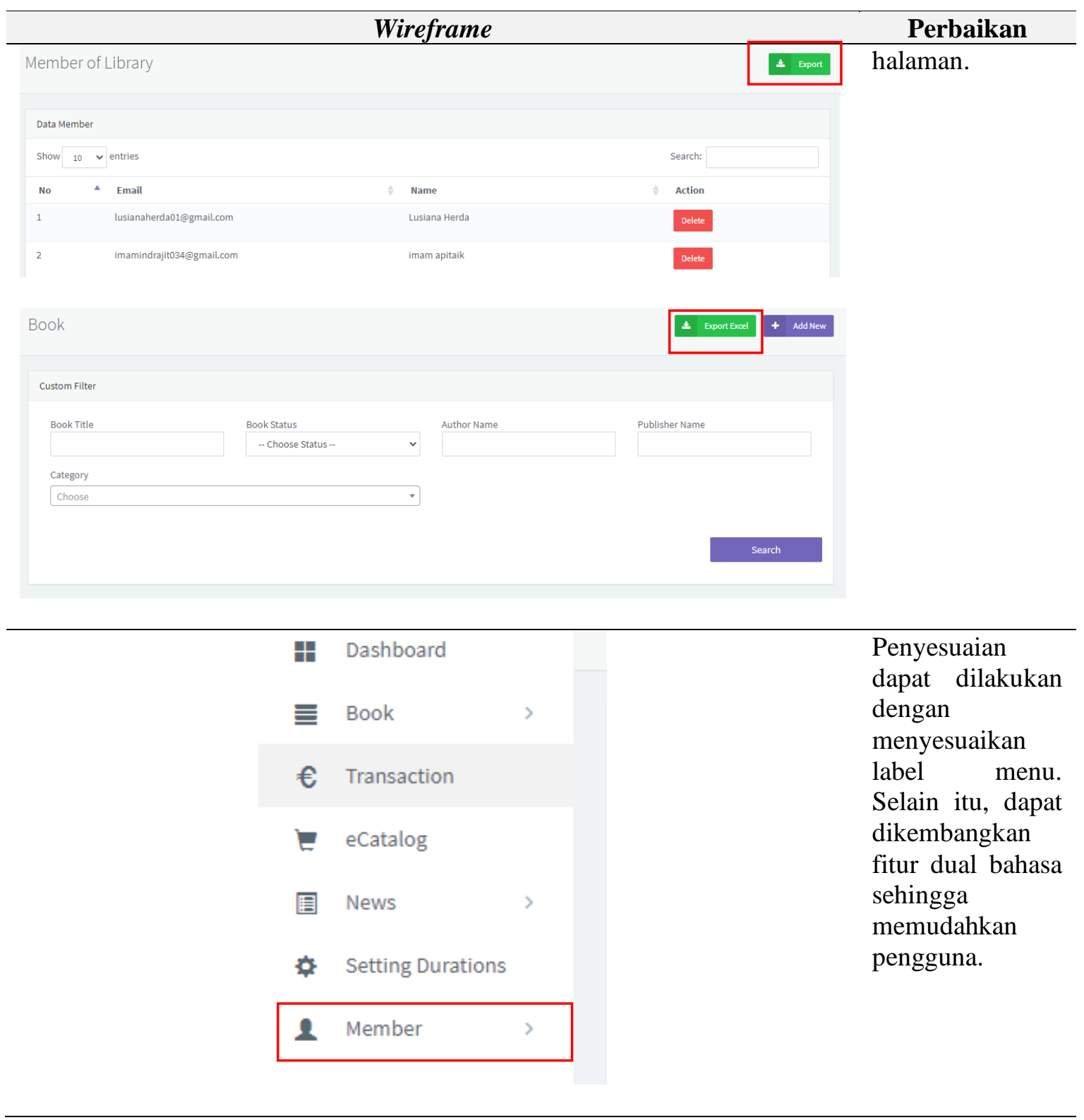

\section{Kesimpulan}

Hasil analisis kepuasan pengguna menunjukkan bahwa 4 aspek pengalaman pengguna ada pada kategori sangat baik. Kategori sangat baik menunjukkan Web Pustakawan berdasarkan aspek daya tarik, ketepatan, stimulasi dan kebaruan termasuk dalam kisaran $10 \%$ hasil terbaik dari produk-produk yang dibandingkan pada benchmark UEQ. Hasil analisis juga menunjukkan bahwa aspek kejelasan termasuk kategori diatas rata-rata dan aspek efisiensi termasuk kategori baik. Sehingga kedua aspek tersebut merupakan prioritas yang harus ditingkatkan dalam melakukan perbaikan halaman pustakawan. Adapun nilai rata-rata setiap aspek adalah sebagai berikut: aspek daya tarik sebesar 1,77; aspek kejelasan sebesar 1,39; aspek efisiensi sebesar 1,65; aspek ketepatan sebesar 1,84; aspek stimulasi sebesar 1,86 dan aspek kebaruan sebesar 1,54. Hasil evaluasi Think Aloud berhasil diperoleh daftar permasalahan yang ada berdasarkan masukan pengguna. Analisis teknik evaluasi Think Aloud berhasil 
I Made Agus Oka Gunawan, I Made Agus Widiana Putra, Kadek Laksmi Damayanthi

memberikan rekomendasi perbaikan pada halaman pustakawan. Hasil analisis menunjukkan bahwa terdapat 10 rekomendasi perbaikan halaman pustakawan Ganeca Digital. Pengembangan untuk penelitian selanjutnya, dapat digunakan teknik lain dalam usability testing, seperti Performance Measurement untuk membandingkan secara kuantitatif hasil evaluasi antara pakar dan pengguna aplikasi. 


\section{BIBLIOGRAFI}

Astuti, Indra, Kusuma, Wisnu Ananta, \& Ardiansyah, Firman. (2017). Analisis Usability Homepage Situs Web Perpustakaan Nasional RI Menggunakan Metode Think-Aloud. Jurnal Pustakawan Indonesia, 15(1-2 SE-Articles). Retrieved from Google Scholar

Dewi, P. W. S., Dantes, G. R., \& Indrawan, G. (2020). User Experience Evaluation Of E-Report Application Using Cognitive Walkthrough (CW), Heuristic Evaluation (HE) And User Experience Questionnaire (UEQ). Journal of Physics: Conference Series, 1516(1), 1-8. Google Scholar

Gupta, Sugandha. (2015). A Comparative study of Usability Evaluation Methods. International Journal of Computer Trends and Technology, 22(3), 103-106. Google Scholar

Hendradewa, Andrie Pasca. (2017). Perbandingan Metode Evaluasi Usability (Studi Kasus : Penggunaan Perangkat Smartphone). Teknoin. Google Scholar

Hinderks, Andreas, Schrepp, Martin, José, Francisco, Mayo, Domínguez, \& José, María. (2019). Computer Standards \& Interfaces Developing a UX KPI based on the user experience questionnaire. Computer Standards \& Interfaces, (January), 19. Google Scholar

Indrawan, Gede, Gunawan, I. Made Agus Oka, \& Sariyasa. (2020). The usability evaluation of academic progress information system (SISKA-NG). Advances in Science, Technology and Engineering Systems, 5(2), 460-468. Google Scholar

Indriyani, Ni Luh Putu Ratih, Dantes, Gede Rasben, \& Ernanda, Kadek Yota. (2017). Analisis Kebermanfaatan Website Sekolah Tinggi Pariwisata ( Stipar ) Triatma Jaya Menggunakan Metode Usability Testing. International Journal of Natural Science and Engineering, 1(2), 55-64. Google Scholar

Mochammad Aldi Kushendriawan, Harry Budi Santoso, Panca O. Hadi Putra, \& Martin Schrepp. (2021). Evaluating User Experience of a Mobile Health Application 'Halodoc' using User Experience Questionnaire and Usability Testing. Jurnal Sistem Informasi, 17(1 SE-Articles), 58-71. Google Scholar

Nurdin, Muhamad. (2020). Mengukur User Experience Sistem Informasi Akademik. Infotech Journal, 6(1), 7-10. Google Scholar

Paramitha, A. A. Istr. Ita, Dantes, Gede Rasben, \& Indrawan, Gede. (2018). The Evaluation Of Web Based Academic Progress Information System Using Heuristic Evaluation And User Experience Questionnaire (UEQ). Proceedings of the 3rd International Conference on Informatics and Computing, ICIC 2018. Google Scholar

Pratama, M. Iqbal Farras, Az-Zahra, Hanifah Muslimah, \& Setiawan, Nanang Yudi. 
I Made Agus Oka Gunawan, I Made Agus Widiana Putra, Kadek Laksmi Damayanthi

(2019). Evaluasi Usability Menggunakan Metode Think Aloud dan Heuristic Evaluation pada Aplikasi Mobile Padiciti. Jurnal Pengembangan Teknologi Informasi Dan Ilmu Komputer, 3(9), 8390-8399. Google Scholar

Putri Ambarwati, \& Metty Mustikasari. (2021). Usability Evaluation of the Restaurant Finder Application Using Inspection and Inquiry Methods. Jurnal Sistem Informasi, 17(2 SE-Articles), 1-17. Google Scholar

Roni, Mochammad Imam Sya\&\#039;, Kharisma, Agi Putra, \& Amalia, Faizatul. (2018). Perbandingan Hasil Metode Evaluasi Usability Antara Heuristic Evaluation dengan Think Aloud pada Kasus Web FILKOM APPS untuk Mahasiswa. Jurnal Pengembangan Teknologi Informasi Dan Ilmu Komputer, 2(2), 674-678. Google Scholar

Santoso, Harry B., Schrepp, Martin, Yugo Kartono Isal, R., Utomo, Andika Yudha, \& Priyogi, Bilih. (2016). Measuring user experience of the student-centered Elearning environment. Journal of Educators Online, 13(1), 58-79. Google Scholar

Schrepp, Martin. (2019). User Experience Questionnaire Handbook Version 8. Google Scholar

Schrepp, Martin, Hinderks, Andreas, \& Thomaschewski, Jörg. (2017). Construction of a Benchmark for the User Experience Questionnaire (UEQ). International Journal of Interactive Multimedia and Artificial Intelligence, 4(4), 40-44. Google Scholar

Tantri Fajarini, Putu, Ayu Wirdiani, Ni Kadek, \& Arya Dharmaadi, I. Putu. (2020). Evaluasi Portal Berita Online pada Aspek Usability Menggunakan Heurtistic Evaluation dan Think Aloud. Jurnal Teknologi Informasi Dan Ilmu Komputer; Vol 7, No 5: Oktober 2020DO - 10.25126/Jtiik.2020753587, 7(5), 905-910. Google Scholar

Wijaya, I. Nyoman Saputra Wahyu, Santika, Putu Praba, Iswara, Ida Bagus Ary Indra, \& Arsana, I. Nyoman Alit. (2021). Analisis dan Evaluasi Pengalaman Pengguna PaTik Bali dengan Metode User Experience Questionnaire (UEQ). Jurnal Teknologi Informasi Dan Ilmu Komputer, 8(2), 217-226. Google Scholar

\section{Copyright holder:}

I Made Agus Oka Gunawan, I Made Agus Widiana Putra, Kadek Laksmi Damayanthi (2021)

First publication right:

Syntax Literate: Jurnal Ilmiah Indonesia

This article is licensed under:

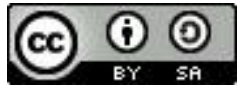

